 \\ ${ }^{1}$ Al-Farabi Kazakh national university, Kazakhstan, Almaty, \\ e-mail: crimedep2016@gmail.com, tapalova_r@mail.ru, daubassova@mail.ru \\ ${ }^{2}$ Atyrau state university named after H. Dosmukhamedov, Kazakhstan, Atyrau, \\ e-mail: asem_tulegenova9@mail.ru
}

\title{
ABOUT STRUCTURE OF CRIMINALISTIC RESEARCH OF DOCUMENTS
}

This article discusses one of the most important and interesting in its structure and importance in the field of applied science and practical science of criminology and jurical expertology focused on the study of techniques and methods for effective and objective investigation and disclosure of criminal offences, which somehow meet the documentation and the cash-paper money, etc. In this connection, one of the most important areas of forensic engineering and technology is a forensic investigation of documents.

We all know that documents occupy a huge and important place in the life of every person, and in the criminal world they have always been either a means of implementing criminal plans, or the subject of criminal encroachment, so documents are more or less common in almost all types and manifestations of illegal acts. For many decades, criminologists have developed methods and techniques for establishing the circumstances associated with document manipulation, using them to steal significant funds or falsify documents for various purposes, starting with the Commission of murder or smuggling, ending with fraud, theft, forgery, etc.

Today, it should be noted that the research of criminal sciences in this area has formed three main branches - graphology, forensic author identification (handwriting), technical and forensic studies of documents, which are closely related to the corresponding types of forensic examination.

Key words: forensic science, forensic examination, forensic examination of documents, handwriting, forensic techniques, forgery of documents and etc.

\author{
Қ. Аратұлы1 ${ }^{1}$, Р.Б. Тапалова', С.Ш. Ааубасова', А.А. Толегенова² \\ 'Ә^-Фараби атындағы Қазақ, ұлттық университеті, Қазақстан, Алматы қ., \\ e-mail: crimedep2016@gmail.com, tapalova r@mail.ru, daubassova@mail.ru \\ ${ }^{2}$ X. Аосмұхамедов атындағы Атырау мемлекеттік университеті, Қазақстан, Атырау қ., \\ e-mail: asem_tulegenova9@mail.ru \\ Құжаттарды криминалистикалық зерттеудің құрымымы туралы
}

Бұл мақалада криминалистика және сот сараптамасы ғылыми-қолданбалы және тәжірибелік ғылым саласындағы өзінің құрылымы мен маңыздылығы жағынан аса маңызды және қызықты мәселелерге қатысты сұрақтар қарастырылған. Оларға ақша-қағаз белгілері мен құжаттар және осы тектес өзге де құра^дар жиі кездесетін қылмыстық құқық бұзушылықтарды тиімді және объективті тергеудің әдістері мен тәсілдерін зерттеуге және ашуға бағытталған мәселелерді жатқызамыз.

Біз білетіндей, құжаттар әр адамның өмірінде үлкен және маңызды орын алады, ал қылмыстық, әлемде олар әрдайым қылмыстық ойды жүзеге асырудың құралы немесе қылмыстық қол сұғушылықтың пәні болып табылады, сондықтан құжаттар заңға қайшы жасалатын әрекеттердің барлық көріністерінде қандайда бір мөлшерде кездесуі мүмкін. Соңғы онжылдықтарда криминалист-ғалымдар және зерттеушілер құжат айналымының манипуляцияларымен, қомақты қаржы мөлшерлерін талан-таражға салумен, түрлі мақсаттағы құжаттарды жалған жасаумен, жалпы айтқанда, кез келген қылмыстық әрекетпен байланысты тергеуге маңызды жағдайларды анықтау әдістері мен тәсілдерін зерттеп сәйкесінше қалыптастырып келеді.

Бүгінгі таңда осы бағыттағы криминалистикалық зерттеулер үш негізгі саланы қалыптастырғанын атап өткен жөн, оларға - графология, сот автортану сараптамалық зерттеулері (қолжазбатану), сот сараптамасының тиісті түрлерімен тығыз байланысты құжаттарды техникалық-криминалистикалық, зерттеу.

Түйін сөздер: криминалистика, сот сараптамасы, құжаттарды криминалистикалық зерттеу, қолжазбатану, криминалистикалық техника, жалған құжаттар жасау және т.б. 


\title{
К. Аратулы ${ }^{1}$, Р.Б. Тапалова, С.Ш. Ааубасова, А.А. Толегенова² \\ ${ }^{1}$ Казахского национального университета имени аль-Фараби, Казахстан, г. А^маты, e-mail: crimedep2016@gmail.com, tapalova r@mail.ru, daubassova@mail.ru \\ ${ }^{2}$ Атырауский государственного университета имени Х. Аосмухамедова, Казахстан, г. Атырау, e-mail: asem tulegenova9@mail.ru \\ О структуре криминалистического исследования Аокументов
}

\begin{abstract}
В данной статье рассмотрены вопросы одной из важнейших и интересных по своей структуре и значимости в области научно-приклаАной и практической науки криминалистики и судебной экспертологии, направленные на изучение приемов и методов эффективного и объективного расследования и раскрытия уголовных правонарушений, гАе так или иначе встречаются Аокументация и средства денежно-бумажных знаков и т.А. В связи с чем одним из важнейших направлений криминалистической техники и технологии является криминалистическое исследование документов.

Все мы знаем, что документы занимают непосредственно огромное и важное место в жизни каждого человека, а в преступном мире они всегда были либо средством осуществления преступных замыслов, мибо предметом преступного посягательства, поэтому Аокументы, в большей или в меньшей степени, встречаются практически по всем видам и проявлениям противоправных деяний. На протяжении многих десятилетий криминалисты разрабатывали методы, приемы установления обстоятельств, связанных с манипуляциями документооборота, использованием их Аля хищения значительных денежных среАств или фальсификации Аокументов в различных целях, начиная с совершения убийства либо контрабанды, заканчивая мошенничества, кражи, подлога и т.А.

Сегодня следует констатировать, что исследования криминалистики в этой области сорормировали три основных отрасли - графологию, судебную автороведческую экспертизу (почерковедение), технико-криминалистические исследования документов, тесно связанные с соответствующими видами судебной экспертизы.
\end{abstract}

Ключевые слова: криминалистика, судебная экспертиза, криминалистическое исследование документов, почерковедение, криминалистическая техника, подАелка документов и т.А.

\section{Introduction}

Let's start in order with the forensic accounting examination. Forensic accounting expertise and forensic examination of documents share a common object. In these areas of forensic knowledge the object of direct study are the documents, the content of which is the actual data, evidence of offenses. In the study of documents on the basis of the evidence base is built. Thus, the term "document" is like the "essence" of all the areas (handwriting, author identification (judicial speech study or forensic linguistics), technical and forensic document examination), including forensic accounting.

The purpose of the article is to consider the concept of "document-evidence" as a collective concept, and to show the difference between each industry, studying c forensic positions of the objectdocument components. The purpose of our research (Lyapicheva, 2001: 28):

1. show the subject and objectives of judicial handwriting and the basic essence of the scientific competence of the forensic expert;

2. show the subject and objectives of judicial speech and the basic essence of the scientific competence of the forensic expert;
3. show the subject and objectives of technical and forensic research of documents and the basic essence of the scientific competence of the forensic expert;

4. show the subject and objectives of forensic accounting and the basic essence of the scientific competence of the forensic expert.

Methodological and theoretical basis of the research. The basis of research is the generally recognized methodology of scientific knowledge. Among the methods that allowed to carry out the analysis of the problem, system-structural, historical, comparative-legal, formal-logical were used. The legal sources of the research are normative legal acts regulating the process of documentation. The theoretical basis of the research was scientific works in the field of criminal procedure, theory of forensic evidence, criminology, theory of forensic examination, forensic accounting and audit (Skoric, 1985: 120).

The main part. In the scientific literature there is no definition of "Document". The conventional view that the document (from lat. documentum - "anything that can serve as evidence, lesson, example" - is a material object on which c using signs, symbols, etc. elements of natural or artificial 
language recorded information about the facts. All variety of documents can be divided into official and informal (private - personal notes, letters, drafts, lecture notes, etc.)) (Vorobyova, 1999: 8-9). Official can come from state bodies, legal entities, citizens (for example, a complaint, a statement of claim, etc.) from a legal point of view, it is characteristic for official documents that legal relations arise on their basis. For official documents, there are some General requirements that must be met by any of them:

a) provide information on certain circumstances and facts. The source of this information must be available so that it can be installed and verified if necessary;

b) information on the facts and circumstances reflected in the document shall be relevant to the merits of the case;

c) data on circumstances and the facts containing in the document shall be stated and certified by organization or the official within their competence, and if the document proceeds from the citizen within its powers and actual knowledge (Zinin, 2002: 87).

If the document does not satisfy at least one of the listed requirements, it cannot be accepted as reliable.

Official documents, in addition, must be made in a certain form and have details. Details are called mandatory data, which in accordance with the established requirements must be contained in the document: prints of stamps, seals; signatures of authorized persons; information about the procedure for the preparation and production of the document (number of printing order, volume of circulation, etc.); form required for some documents (power of attorney, invoice, etc.). Official documents issued by citizens do not always have a strictly established form, but they must include: the name and patronymic of the applicant, his address, the name of the institution and the person to whom the document is sent. The document is signed by the originator (author) (Lyutov, 1993: 45).

Among the official documents are documents of strict accountability, forms of which are made in full compliance with co standards approved by state bodies - the Government of Kazakhstan, the Ministry of internal Affairs, the Ministry of foreign Affairs, MF RK, the National Bank of Kazakhstan, MES RK, etc. The standards provide not only the form of forms, but also the rules of their manufacture (including the relevant materials, printing method), the rules of filling, issuance, destruction in connection with the expiration of their use. Forms of the strict accounting are made only in specialized printing house, surely have number and a series of the form. Depending on the importance of the document, forms have different degrees of protection against forgery. The maximum number of levels of protection have forms of banknotes, foreign, diplomatic passports, diplomas, identity cards, driver's licenses, etc.

There are genuine and forged documents. In turn, the original documents stand out valid and invalid (for example, a certificate or pass, the validity of which has expired). The original document, executed in the prescribed or accepted form, may be valid and invalid. Valid is a document that is currently valid (for example, a power of attorney that has not expired); invalid is a document that has spent legal force (for example, the same power of attorney that has expired) (Nikolaev, 1996: 95).

Documents, the content of which is aimed at the implementation of criminal intent, are considered fake. Methods of production of such documents conditionally distinguish into two types: intellectual or material forgery. In case of intellectual forgery, the document has all the necessary details, drawn up and signed by an authorized official, with the help of the same means and materials of the letter, which are used for registration of original documents. However, when the document was used about the content of information (Yurov, 1998: 12-13). The fact of intellectual forgery cannot be determined by technical and forensic methods. This type of forgery is established in the process of investigative and operational activities with the involvement of specialists - auditors, auditors, economists, financiers, accountants, technologists, commodity experts, the appointment and conduct of forensic economic, handwriting examinations, sometimes to prove appointed technical and forensic examination of documents.

The essence of material forgery is that the authenticity of the document is violated by encroachment on the details, materials of the document, the use of non-GOST printing means (for example, the form of a banknote should be made with the help of a high seal, offset, etc.)., the offender uses a color printer) (Safronenko, 1999: 95-96).

Criminologists distinguish two types of forgery: full and partial.

Full fake - the production of the blank document to fill it (e.g., entering text, signing, drawing stamp, sticker photos, etc. requisites'.)

Partial forgery - changes are made to the original document-replacement of the photo, changes in the content of the text, etc.). 
The concept of authenticity refers to the legal characteristics of the document, reflecting the truth of the information recorded in it about the events and facts of legal significance, the correctness of all the details (external form) and the proper source of origin (design) of the document. Establishment of "authenticity", "falsification" of the document is not within the competence of the expert and the expert as these concepts have legal character and are a prerogative of bodies of inquiry, the investigator, Prosecutor's office and court. A specialist or expert in the results of the research reflects the decision of the technical side of the established fact (for example, "the numbers are added to the number", "the image of the print is obtained with the help of an electronic photographic devices", etc.) (Sosenushkin, 1996: 201-205).

From a procedural point of view, all documents are divided into three groups:

1) documents - material evidence;

2) documents - written evidence;

3) sample documents for comparative study (online.zakon.kz).

In accordance with co article 120 of the code of criminal procedure documents become evidence: "1. ...if the data stated or certified in them by physical, legal and officials, are important for criminal case.

2. Materials in which the actual data on illegal actions obtained in compliance with the requirements of the Law of the Republic of Kazakhstan "On operational investigative activities" are recorded are documents and can be used in criminal proceedings as evidence.

3. Documents may contain information recorded in writing or in any other form...”.

In accordance with co article 118 of the code of criminal procedure: "material evidence are objects and documents that can serve as a means to detect a criminal offense, establish the actual circumstances of the case, identify the guilt of a person or refute his guilt or mitigation of liability."

Thus, the objects of forensic research are documents - physical evidence, in solving identification issues are further studied and conducted a comparative study of sample documents.

The main difference between the document material evidence from other types of documents is that they reflect the actions of the offender, for example, a signature made by the offender, a print of a homemade seal, a form printed with a homemade cliché, a photo glued by the offender, a text composed by the offender, etc., this is unique, irreplaceable and irreplaceable in case of loss of this material evidence.
With all its diversity, the documents as material evidence related to the investigated event, according to A.F. Aubakirov, can be differentiated into the following categories:

1) documents as a means of committing a crime: fake accounts, invoices, statements, acts of acceptance of repair work, write-off, etc.;

(2) documents as a means of concealing a crime, such as suicide letters allegedly on behalf of the victim, anonymous letters, false passports, certificates, etc.;

3) documents as direct objects of encroachment: stolen, burned or torn documents - contracts, wills, etc.;

4) documents as a means to facilitate the disclosure and investigation of crimes and establish the essential circumstances of the case (Aubakirov, 2002: 32).

"Document-physical evidence" in criminology is perceived in a broad sense - as a source of evidentiary information in text or graphic form, executed in any way and on any media: handwritten, typographic or typewritten way, drawn, drawn or engraved, with the possible unusual media (for example, spoon c scratched numbers or letters, matchbox c written on the surface of the ee words, etc.).

Given the uniqueness of the objects of forensic research, developed General rules of inspection, seizure and fixation of documents - physical evidence.

Inspection of documents as a procedural action is widely used in the investigation of economic, environmental, official and some other types of criminal offenses, in the consideration of administrative offenses and civil cases. Prior to and during the examination of the document, measures should be taken to avoid the possibility of modification, damage or destruction of traces of partial or complete forgery on the document. When working with documents, it should be borne in mind that they may have traces of hands, micro particles of foreign substances, etc. Therefore, when handling them, it is necessary to use tweezers with rubber tips, rubber gloves, paper corners to preserve traces for subsequent forensic studies (Snetkov, 1987: 89-91).

During the inspection, special technical means are used - special illuminators that allow you to view the document in shadowless, directional lighting, on the lumen, in ultraviolet, infrared rays, magnifying devices - magnifiers of different multiplicity, measuring tools. Examination of the document, if necessary, is possible with the participation of a forensic specialist or a specialist in the field of other professional activities, depending on the 
type and purpose of the document under study (for example, an inspection with the participation of an accountant or technologist, etc.). Sometimes during the examination of documents, the judge (investigator, investigator) may pre-request from the relevant government agencies, commercial organizations original documents for comparison with the documents-physical evidence in the case.

Inspection begins with the definition of the name, type, purpose of the document and familiarization with its contents. If the document refers to the documents of strict accountability, checked compliance with ESOG on the appearance of the form, the availability of protective equipment and the absence of any changes. Attention is drawn to the correspondence of the content of the text to the generally accepted forms of drawing up similar documents, the correspondence of the date of drawing up the document specified in it, to the real events described in the document, to the presence of signs of material forgery - cleaning, etching, additions, replacement of sheets in multipage documents, etc. During the inspection, signs of technical changes may not be detected. The right of the judge (investigator, investigator) to send documents to handwriting, technical and forensic, accounting and other examinations (Vul, 2007: 26).

Documents - material evidence cannot be filed in the case. It is recommended to store them in a separate envelope of the appropriate size. Bend the document according to the folds. Dilapidated and torn documents for storage and use in the production of investigative actions should be placed in transparent envelopes made of polyethylene (files). When sending documents, they are Packed in tight envelopes between sheets of clean paper so that they are not punctured, stitched with threads, filled or stained with glue or wax.

Fixing the results of inspection performed in the inspection report drawn up in accordance with the norms of the code of criminal procedure, code of civil procedure of the RK, of the administrative code. It indicates the place, date and time of discovery of the document; the sender, from which it was received; the name of the document, its registration number, date of issue, on behalf of the institution and in whose name issued, what details certified; the size of the document; the nature of the edges; the presence of folds, gaps, stains and dirt; characteristics of paper, dye, revealed during the inspection signs of forgery and material forgery.

The content of non-standard documents, small in volume, fits into the Protocol completely. If the text volume or it has secret character, in the Protocol the initial and last words of the text of the document are given.

As an additional method of fixation according to the rules of forensic photography should be made photographing the place of detection of the document, its General appearance and fragments of orienting, survey and detailed shooting.

Forensic investigation of documents carries out scientific and methodological support of the decision of problems of proof. Scientific and methodological support means the contents of the special knowledge of involved experts, their scientific competence, i.e., what knowledge should have a specialist for the solution of proof of establishing actual data. Investigative practice illustrates how wide the range of scientific knowledge in the forensic study of documents. It can be stated that none of the physical evidence used in the detection and investigation of crimes does not require the involvement of such different specialists. In the forensic study of documents involved lawyers, philologists, linguists, economists, accountants, financiers, technologists, chemists, biologists, specialists in the printing industry, etc. The reason is obvious, the concept of "document" is a complex, collective concept that reflects not only the technology and the whole process of its manufacture, but also reflects the process, the content of the actions recorded in the document, which are diverse - it can be the mental activity of the author of the text, it can be the process of movement of funds, real estate, services, payment, production, etc., including the actions of the criminal on forgery (Filippov, 2004: 201).

The scientific competence of experts involved in the forensic study of documents varies significantly.

Traditional and developed is considered to be the branch of forensic research documents - is handwriting.

Handwriting is a branch of forensic knowledge that studies the laws inherent in human handwriting, and on their basis, developing recommendations for the collection of handwriting samples and scientifically based methods for the study, use of handwriting material in order to establish the circumstances of civil, criminal or administrative proceedings.

The objects of handwriting in the document are handwritten notes, signatures and symbols, signs, necessarily made by human hand.

The subject of graphology is the study of regularities of formation, development and functioning (symptoms) and changes in the skill (PD FDK) that lay at the basis of the handwriting; the study of patterns an expert study of handwriting; 
development based on identified patterns of recommendations for investigators (investigators), prosecutors, judges, lawyers in the preparation of materials for appointment is forensic handwriting examination.

The tasks of judicial handwriting are divided into classification, diagnostic, situational and identification. Features of handwriting are that all tasks (classification, diagnostic, situational and identification) are solved only with the help of a forensic expert and a specialist in the field of handwriting.

Classification tasks are related to the establishment of sex, age, level of education of the performer of records or signatures.

Diagnostic and situational tasks are associated with the establishment of the influence of certain factors on the performance of manuscripts (signatures), as well as the establishment of certain types or specific conditions of writing: alcohol or drug intoxication, stress due to threat, blackmail, or the fact of intentional distortion of his own handwriting, imitation of another person's handwriting, unusual posture, etc.

Identification tasks are the tasks of establishing the existence or absence of an individual identity of a particular performer of the handwritten text, separate fragments of the text, records (alphabetic or digital) and signature, as well as the establishment of the fact of performance by one or different persons of various handwritten texts, its separate fragments and signatures.

Thus, the scientific competence of the expert handwriting consists in knowledge of the properties inherent in human handwriting. Handwriting is a system of movements of the human hand, with which on the substrate (paper or other) are conditional graphic characters (individual letters, words, sentences, signature and other, such as dashes, commas, etc.). A system of hand movements, recorded in manuscript or signature, is produced in the process of human learning within a certain time email, i.e. the person gets a written-motor skill, there is a dynamic stereotype.

The formation of written-motor skills has a complex psycho-physiological nature. Psychophysiological mechanism of writing is as follows in the process of learning the movement of the hand in the form of a conditioned reflex are fixed in the cerebral cortex according to the configuration of the sign of the alphabet. The level of formation of written and motor skills is influenced by many factors - the anatomical structure of a person, his psyche, physiology, methods of teaching writing, the number of exercises, profession, etc. A.I. Mantsvetova, V.F. Orlova, etc., and also by Kazakh scientists V.A. Hwan, E.G. Djakishev, T.T. Kulteleev, N.A. Jangeldin, L.S. Shabaev, etc.

The regularities inherent in human handwriting - individuality, relative stability and variability were established. Listed and not named previously working and now working the experts had or have a legal education, the practice has shown that knowledge in the field of criminology, obtained during training, are adequate platform for the development of such a complex and subjective area of knowledge.

Individuality of handwriting is a set of properties and features of handwriting that determine its originality and uniqueness in different persons. Individuality of handwriting is due to objective and subjective factors. Expert practice does not know a single case where the handwriting of different people would be exactly the same.

Formed handwriting of each person is stable and at the same time, to some extent, variation. Under variation handwriting should be understood kind of configuration signs, eponymous letters, for example, when writing a capital letter " $\mathrm{t}$ " can be several options. Under the influence of external and internal factors (for example, high temperature, alcohol or drug intoxication, threat, etc.), changes in handwriting can occur. Electoral volatility, as the property has the same value for the diagnosis as personality traits and stability of handwriting for identification.

Forensic investigation of signatures - a signature is a special type of manuscript that denotes the name (sometimes first name and patronymic) of a person in the form of letters or conventional written signs and has a certified purpose. It should be noted that there is a tendency to increase the number of signature examinations rather than handwritten records.

The signature, being a graphic style, is connected with handwriting by unity of psychophysiological bases, technical and graphic skills of the letter. However, the process of signing takes place in a shorter period of time, on the basis of already formed PD FDK skills. This is primarily due to the brevity of the typefaces and the frequency of repetitions of the same movements. Movement while performing signature during long-term training achieve the greatest level of automaticity: in the signature occur original build, make when writing individual characters and their combinations, increasing the pace of execution; the signature takes the form of the usual ideogram.

Judicial author registration - the traditional direction of forensic technology, the beginning 
of the formation was laid in the middle of the last century by Soviet forensic scientists, is based on the data of linguistics, including Philology and other areas of knowledge about language and speech, on the system of knowledge about the conditions and patterns of human speech behavior.

Judicial author registration was designed to solve problems of an identification and non-identification nature.

Recently, due to changes in the Civil code of the Republic of Kazakhstan, the Criminal code of the Republic of Kazakhstan, there were judicial precedents on the facts of insult of honor and dignity of citizens, damage to business reputation of a citizen, entrepreneur or legal entity. There were criminal cases on charges of extremism, incitement of hatred or enmity, as well as humiliation of human dignity, etc. These conflicts, which are based on the products of speech activity of people, are resolved during the investigation, trial on the results of linguistic and stylistic analysis, for which philologists were invited (Nurgalieva 2010: 68-69). Thus, the linguistic expertise was formed. Today, among the linguistic studies are the following groups: examination of controversial speech works in cases of protection of honor, dignity and business reputation; on charges of libel; insult, contempt of court, insulting a representative of the authorities; in extremist activity, as well as on charges of inciting racial, religious, national and social hatred, enmity; and also distinguish linguistic expertise of advertising texts; trademarks.

If we generalize modern linguistic research and the traditional direction of "authorology", it is noted that the objects they have the same - it's words, morphemes, combinations of words or sentences, texts, t. e. products of speech activity. Fixation of products of speech activity can be very different an article in a newspaper, magazine, speech on TV, radio, videos, texts, leaflets, texts on electronic media - discs, flash drives, it can be promotional products, etc. For speech research it does not matter whether words, texts are made by hand, on a computer or by printed means (offset, high, etc.).

The object is speech works of any volume and quality. Currently, two names for objects of linguistic research compete with each other - these are, on the one hand, products of speech activity and, on the other - text.

Thus, the theoretical and methodological basis of all kinds, subspecies of speech research is the judicial speech of the author-the branch of forensic technology that uses linguistic knowledge in order to establish the refutation of facts that have the status of judicial evidence and are necessary for the resolution of civil, criminal or administrative case.

The tasks of judicial speech are divided into groups: non-identification (classification, diagnostic, situational) and identification.

Classification tasks are connected with the establishment of belonging of the author of the text, words to a certain group of persons by sex, age, social affiliation, professional activity, the establishment of linguistic and stylistic features of the text.

Diagnostic and situational tasks are related to the establishment of the fact of influence on the preparation of the text of certain types (or specific) conditions: alcohol or drug intoxication; the fact of intentional distortion of their own speech skills or imitation of the speech of another person; the establishment of the semantic content of individual words, phrases; tasks, in particular, related to the establishment of facts of slander, insult to the honor and dignity of citizens, damage to the business reputation of a citizen, entrepreneur or legal entity; statements of an incentive nature or phrases in the form of a Directive to act in favour of one social group at the expense of another, to incite hatred or enmity, as well as calls for deportation, repression against representatives of any nation, denomination, ethnic group, etc. (Bychkova, 2005: 117).

Identification tasks include establishing the fact of drawing up a specific text by this subject or the text of various documents by one person, separate fragments of the text of several documents by one person, etc. When identifying, it is necessary to differentiate the subject as the author from the subject of the performer, i.e.. a person who prints or writes someone else's text. Identification of the latter is carried out in the framework of technical and forensic or handwriting examination.

The formation of human speech skills begins at birth. In childhood and early youth formed visual and situational type of thinking, everyday style of speech. As further training (in high school) is the formation of a categorical type of thinking, journalistic and scientific style of speech, mastering the norms of language. Upon receipt of secondary special and higher education, language skills, scientific and journalistic styles are improved, with the appropriate practice of public speaking can develop the skill of using public speaking style (Arzumanyan, 1975: 56-57].

At the end of the training stage and the formation of personality, his speech skills acquire relative stability. A person's speech skill is formed under the influence of many factors. Forensic scientists have identified the following patterns of human 
speech behavior - individuality, relative stability, variability. The individual characteristics of the person, his psychological makeup, the cultural level of the surrounding persons, school, chosen profession, and more determines the individuality of the speech skills of a person and its stability. Due to the peculiar conditions of personality formation, each person acquires individual speechthinking skills, manifested in the fact that he does not possess the whole set of existing norms, but only a certain set of them, and also uses in his speech practice not the whole set of properties of the norm, but only a certain part of them, which he usually gets used to using. Thus, the complex of individual language and intellectual skills of a particular person is unique and inimitable in each specific speech situation and allows to identify the author of a particular text.

The relative stability of human speech behavior has a psychophysiological basis, at a certain stage of human development as a person develops a stereotype of behavior.

Speech behavior of a person due to a specific communication situation, with him as the author and his addressees (anthropocentrism). Variability of speech behavior takes place in the oral and written speech of a person, but the individuality of speech skills of a person is preserved. General provisions of the methodology for the study of human speech skills are universal, regardless of the language in which the document is made. Thus, the scientific basis of judicial speech and, accordingly, the scientific competence of the expert is based on the provisions of Philology, linguistics, but practice has shown that this is not enough, we need knowledge of criminology. especially in the field of private teaching of forensic identification, in the application to the solutions of the problems of legal proceedings, form the true content of the scientific competence of the expert on speech examination.

Technical and forensic research of documents is an industry established on the basis of theoretical and special methods borrowed from the field of natural and technical Sciences, in order to establish the facts in connection with the investigation of criminal cases or the resolution of civil disputes, as well as in some cases when considering cases in an administrative court or in the process of notarization of documents.

The objects of technical and forensic research documents are:

1) details of documents, which include texts, signatures, resolutions, dates, seal impressions, stamps, photos, document forms;
2) materials of documents: materials of the letter - ink, ink, pastes for ballpoint pens, paints, rods for pencils, electrographic toners; material on which the document is made (paper, cardboard, etc.), auxiliary substances (glue, wax), and also substances used for partial or complete change of the document (etching substances, solvents, etc.);

3) technical means and adaptations used for production of forms of official documents or their details (seals and stamps, tools of the letter - pens, pencils, composters, sign printing devices, letters of the font, perforators, tools for destruction of strokes cleaning, etc.) or for modification of earlier made documents;

4) atypical for this type of research objects on which there could be slightly visible or invisible records (pieces of plywood, fabric, ceramics, wooden covers, etc.);

As part of the technical and forensic study of the documents, the following classes of tasks are distinguished: diagnostic, identification and classification (Ochichenko, 1998: 64).

Classification tasks arise if necessary to refer to a predetermined class of objects, for example, to establish the type, system, model of the printing medium, the type of dye in handwritten notes, the class and consumer purpose of the paper used for the manufacture of the document form, etc.

Diagnostic tasks are aimed at establishing the method of making the document (handwritten, printing, photographic, typewritten, by re-copying), the fact and method of changing the original content of the documents (cleaning, etching, addition, reprint, etc.); the original content of the documents (restoration of invisible and poorly visible records - cleaned, etched, drenched, crossed out, smeared, faded, exposed to high temperatures, etc.).); time of production of the document (absolute and relative prescription), including chronological sequence of the crossed strokes.

Identification tasks are associated with the identification of technical means used in the manufacture of the document as a whole or its individual details (typewriters, printed forms, seals, stamps, multipliers, writing instruments, etc.), document materials (paper, cardboard, dyes, glue, wax, etc.); whole on its parts (restoration of the torn documents on scraps of paper).

The solution of some problems is based not only on the provisions of STID, but also on the methodological foundations of trace science (for example, in the identification of printed materials, printing, stamps, etc.), forensic research of materials, substances (for example, in the identification of 
dyes of writing materials, determining the consumer purpose of paper, etc.).

It is not difficult to understand that the scientific basis of technical and forensic research documents and, accordingly, the scientific competence of the expert is based on the provisions of the mother Sciences - materials science, science, studying the properties of objects of the material world-physics, chemistry, printing, technology, etc. however, practice has shown that in this area is not enough of this knowledge, we need knowledge of criminology. especially in the field of private teaching of forensic identification, in the Annex to the solutions of the problems of legal proceedings, all together form the true content of the scientific competence of the expert on technical and forensic examination.

Judicial accounting as a forensic area of knowledge studies the financial and economic activities of the subject in the framework of accounting. According to St. 6 and 7 of the Law "On accounting" all financial and economic activities of an economic entity should be reflected in written and electronic form. The direct objects of research of judicial accounting are accounting documents - primary documents, accounting registers (journals-orders, statements), documents of financial statements.

The subject of forensic accounting are the actual data established on the basis of special scientific knowledge, which show how the enterprise, firm, institution (economic entity) conducted accounting, as financial and economic activity is reflected in the accounting documents, on what operations there is an incorrect accounting, etc. Tasks solved by the judicial accounting, are diagnostic and situational nature and are divided into three groups.

The first group of tasks is to identify the discrepancy between the data of primary documents and the data in the accounting registers and the data in the reporting, the amount of differences that exist in this case.

The second group of tasks solved with the help of forensic accounting expertise, aimed at determining the reception, storage, sale of inventory, cash on accounting documents.

The third group of tasks is related to the establishment of the circumstances of the correctness of accounting, as well as circumstances that specifically complicate the identification of shortages or surpluses.

To solve the above issues, the investigator is obliged to provide primary accounting documents (these include - invoices), accounting registers (journals, orders, statements, General Ledger), accounting materials (balance sheets, reports).
In addition to these documents, the expert is provided with electronic media - disks with the required information, the withdrawal of which is carried out with the requirements of the criminal procedure code and forensic tactics. It is necessary to provide materials of operational accounting, statistical accounting, draft journals, inventory acts, contracts of full liability, employment contracts, etc.

But in the investigation of offenses in the field of economy, such as illegal business, illegal banking, pseudo-entrepreneurship, economic smuggling, deliberate bankruptcy, false bankruptcy, illegal loan or misuse of budget credit, etc. offenses cannot be limited to accounting, the object of the study should be all financial and economic activities of the economic entity.

The subject of proof are the circumstances that indicate the economic and financial condition of the enterprise, institution, organization, i.e. the subject is much wider in comparison with the examination of accounting documents.

Depending on the tasks to be solved, the subject, the study of financial and economic activity is divided into 3 types: financial and credit research; financial and budgetary research; economic and legal research.

Financial and credit expertise is necessary to study the validity of the formation, expenditure of cash funds and distribution of loans. Financial and budgetary expertise is necessary to study the validity of budget spending, to establish the correctness of tax reporting documents and others within the budget.

Examination of economic and legal research - within the framework of forensic economic and legal research, the problems of compliance of contractual relations with the legislation in force for the period under study are solved. It is appointed, as a rule, in criminal proceedings in the investigation of abuse or abuse of authority of officials and others provided for in the Special part of the criminal code. Sometimes in appointment there is a need in the investigation of crimes: false bankruptcy, deliberate bankruptcy, tax evasion, non-repayment of credit, illegal privatization, etc.

The study is subject to arising in the course of implementation of economic and other types of legal relations in the following main areas: relations arising in the process of public procurement; obligations on taxes and other payments to the budget; relations related to the implementation of banking activities; relations arising in the process of privatization; relations related to the implementation of activities subject to licensing; 
relations arising in the field of pensions; civil-legal relations arising from the economic settlements of economic entities, based on both contracts and transactions in General.

Direct objects of research are documents, not only accounting - primary documents, accounting registers (journals-orders, statements), documents of financial statements, but also documentation of organizational and administrative nature, statutory, contractual, production, technological, etc.

Based on the list of the studied tasks, it seems that the name of this direction is better to be called as judicial audit, since it is not limited to accounting documents only, but includes a list of documents covering the entire scope of activity of an economic entity.

The competence of experts, based on the variety of tasks, seems to be delimited. The content of the competence of some experts should correspond to accounting, the competence of others should be based on the provisions of macroeconomics, microeconomics, economic audit, etc.

The results of the research. Analysis of the tasks of forensic research documents shows their incredible diversity, despite a single source of research - documents. The solution of tasks on the documents for the disclosure and investigation of the crime requires the involvement of a wide range of specialists and means that the structure of forensic technology requires a clear differentiation of each area of forensic knowledge - handwriting, speech, technical and forensic examination of documents, forensic accounting (judicial audit). The needs of solving the problems of legal proceedings form the true content of the scientific competence of experts in each industry.

\section{References}

Arzumanyan T.M., Tanasevich V.T. (1975) Buhgalterskaya ekspertiza pri rassledovanii i rassmotrenii ugolovnyh del. [Accounting expertise in the investigation and trial of criminal cases.]. M. p. 108. (pp. 56-57).

Aubakirov A.F. (2002) Kriminalistika: sudebnye tekhnologii [Criminology: forensic equipment]. Almaty, p. 102.

Basics of examination of banknotes: Method, manual / Ed. Vladimir Finogenov and A.V. Yurov. M., 1998. Part 1: Banknotes. p. 208. (pp. 12-13).

Bychkova C.F., Bychkova E.C., Kalimova A.C. (2005) Sudebnyj ekspert. Kurs lekcij: uchebnik. [Forensic expert. Course of lectures: Textbook]. - Almaty: Zheti Zhargy. - $280 \mathrm{c}$.

Filippov A.G., Volynsky A.F. (2004) Criminology: Textbook / Ed. Law and law. p. 460.

Lyapicheva V.E. (2001) Technical and forensic examination of documents: a Course of lectures/ Ed. Volgograd, p 240.

Lyutov V.P. (1993) Detection of counterfeit paper money: a Training manual. p. 120.

Nikolaev A.C. (1996) Inspection and investigation of counterfeit banknotes and securities. SPb. p. 240.

Nurgalieva B.M. (2010) Criminalistics. Studies'. / Ed. Karaganda. p. 170.

Ochichenko I.I., Nersesyan M.G. (1998) Ekspertnoe issledovanie hozyajstvennyh operacij, svyazannyh s polucheniem denezhnyh sredstv ot drugih organizacij: metodicheskie rekomendacii [Expert research business transactions relating to the receipt of funds from other companies: guidelines]. M. p. 240.

Safronenko T.I., Sosenushkin M.N., Belousov G.G. (1999) Forensic study of identification plates (rubber stamp), made on new technologies: Methodological recommendations. No. 1, p 380.

Skoric B. (1985) Actual problems of technical and forensic examination of documents: Collection of scientific papers. Vol. 2. p. 120 .

Sosenushkin M.N. (1996) Osnovy tekhniko-kriminalisticheskoj ekspertizy dokumentov [Basics of technical and criminalistic examination of documents]. M., p. 210. (pp. 201-205).

The type of the material: the textbook / Under ed. V.A. Snetkov. - M., 1987. - p. 112.

Ugolovno-processual'nyj kodeks Respubliki Kazahstan [Code of criminal procedure of the Republic of Kazakhstan] No. 231-V of 4 July 2014 https://online.zakon.kz/document/?doc_id=31575852

Vorobyova I.B., Malanina N.So. (1999) Recognition of forgery. Technical and forensic aspect. Saratov, 1999. p. 234.

Vul C. (2007) et al. Forensic classification based on the analysis of frequency characteristics of the lexical structure of the lyrics // Topical issues of judicial review. (pp. 40-52).

Zinin A.M. (2002) Proverka dokumentov, udostoveryayushchih lichnost': uchebnoe posobie. [Verification of identity documents: Training manual]. M. p. 220. 